\title{
Internal Control and SMEs' Sustainable Growth: The Moderating Role of Multiple Large Shareholders
}

\author{
Liangcheng Wang *, Yining Dai * and Yuye Ding * \\ School of Business, Sichuan University, Chengdu 610065, China \\ * Correspondence: wanglc@scu.edu.cn (L.W.); jjkdyn929@163.com (Y.D.); yuyeding199802@163.com (Y.D.)
}

Received: 22 October 2019; Accepted: 30 November 2019; Published: 4 December 2019

\begin{abstract}
Small and medium enterprises (SMEs) face more risks for sustainable growth due to a lack of resources than large firms in emerging economies. Hence, it is more likely for SMEs to look to risk management for survival in turbulent markets. As a tool of risk management, whether internal control indeed has contributions to the sustainable growth of SMEs, particularly conditional on multiple large shareholders, is empirically unexplored. Using a sample of SMEs listed in China, this study examines the relationship between internal control and sustainable growth, and assesses a moderating role of multiple large shareholders. The results show that effective internal control significantly promotes SMEs to achieve sustainable growth, and the effect is moderated by multiple large shareholders, suggesting that the role of internal control is more prominent in SMEs with multiple large shareholders. These results are robust to a battery of sensitivity tests. This study extends the literature by providing empirical evidence on the role of internal control in SMEs' sustainable growth.
\end{abstract}

Keywords: sustainable growth; internal control; multiple large shareholders; SMEs

\section{Introduction}

Increasing uncertainty and competition in the process of internationalization attaches much more difficulties and risks to small and medium enterprises (SMEs) for sustainable growth than large firms in emerging economies. Particularly in the current time of global economic downturn and burgeoning trade conflicts, SMEs face huge challenges and risks to compete for survival and sustainable growth due to a lack of internal and external resources in a turbulent market. While a considerable body of literature has discussed the factors that significantly contribute to firms' sustainable growth, such as intellectual capital ( $\mathrm{Xu}$ and Wang 2018), international and financial capabilities (Ma Degong et al. 2018; Ye and Kulathunga 2019), technology (Lyver and Lu 2018), innovation and corporate social responsibility in developed and emerging markets (Ge et al. 2018; Hong and Chao 2018), there is little attention paid to the role of internal control as a tool of risk management in SME's sustainable growth in emerging and transition economies.

As the Committee of Sponsoring Organization of the Treadway Commission (COSO 2017) emphasizes, internal control not only is a framework of enterprise risk management, but also integrates with strategy and performance for sustainable growth. Recently, more studies are being called for by COSO (2017) to explore the role of internal control in promoting sustainable growth around the world, particularly in developing economies. To respond to the claims in academia and practice, the purpose of this study is to examine the role of internal control in the sustainable growth of SMEs in the large emerging economy of China.

Effective internal control may promote sustainable growth. First, internal control is used to reduce the likelihood of corporate misconduct and fraud. As well as being exerted from the top down, internal control can also be exercised bottom-up as an important internal governance mechanism providing internal checks and balances to constrain management's ability to extract private benefits 
and expropriate shareholders (Jensen 1993; Bushman and Smith 2001; Acharya et al. 2011). Due to lack of prevention and detection mechanisms, weak internal control provides convenient opportunities for managers to exploit private benefits, which may destroy sustainable growth.

Second, effective internal control is associated with lower capital cost. Effective internal control can reduce corporate risk and protect the interests of investors through a series of procedures and activities, and thus decrease a firm's cost of capital (Beneish et al. 2008; Dhaliwal et al. 2011). Firms with low capital cost have a comparative advantage in resource allocation to create value and competitiveness, which in turn is helpful to promote sustainable growth of the firms.

Third, effective internal control leads to more efficiency of investment and operation. The optimal decision making in investment and operation is based on the information quality provided and assured by internal control. Effective internal control reduces wrong decisions and behaviors of a firm, and hence improves the efficiency of operation and investment by providing high-quality information (Cheng et al. 2013; Cheng et al. 2018). Internal control is not only linked to the efficiency of investment and operation in a firm, but also correlated with the resource allocation efficiency (D'Mello et al. 2017), thereby jointly influencing the firm's sustainable growth.

Accordingly, internal control is assumed to alleviate agency problems and thus exert a governance role by extant literatures, e.g., it is documented that internal control serves as a governance mechanism to constrain managers' ability to extract private benefits from insider trading (Skaife et al. 2013), safeguard corporate resources (Gao and Jia 2016; Qi et al. 2017), curb excessive compensation of executive (Paletta and Alimehmeti 2018), and retain customer-supplier relationships (Bauer et al. 2018). Therefore, internal control is also expected to perform a governance role in sustainable growth.

In addition, the role of internal control in firms' sustainable growth is assumed to be moderated by multiple large shareholders. There are two competing explanations for the effects of multiple large shareholders. In one view, multiple large shareholders not only monitor managers but also each other. As a result, a firm with multiple large shareholders implements better corporate policies (Shleifer and Vishny 1986; Pagano and Röell 1998). In the other view, multiple large shareholders form controlling coalitions and collude to expropriate from minority shareholders (Bennedsen and Wolfenzon 2000). Therefore, it is an empirical issue whether the role of internal control in firms' sustainable growth may be reinforced or weakened by multiple large shareholders.

The above issues are tested by using a sample of SMEs listed in the largest emerging economy of China from 2011 to 2015. Internal control (IC) is measured as an indicator variable that is equal to one if the firm has effective internal controls in a particular fiscal year, and zero otherwise. The sustainable growth rate (SGR) is estimated by adopting the Higgins' model (Higgins 1977). The findings show that effective internal control significantly promotes SMEs to achieve sustainable growth, and the effect is moderated by multiple large shareholders, suggesting that the role of internal control is more prominent in SMEs with multiple large shareholders. These results are robust to a battery of sensitivity tests, including control for endogeneity using the Heckman two-stage procedure, and alternative proxies for sustainable growth and multiple large shareholders.

This study contributes to the literature in several ways. First, our study adds to the emerging literature on the determinants of sustainable growth by examining the governance role of internal control in sustainable growth. Previous studies focus on the role of intellectual capital, international and financial capabilities, technology, innovation, and social responsibility in a firm's sustainable growth (e.g., Xu and Wang 2018; Ma Degong et al. 2018; Ye and Kulathunga 2019; Lyver and Lu 2018; Hong and Chao 2018). This study provides additional evidence on the understanding of internal control as a contributor of sustainable growth.

Second, this study extends the stream of research on the economic consequences of internal controls. Our findings corroborate the claims proposed by COSO (2017) and directly link effective internal control and sustainable growth as evidenced by using a large sample of listed firms in China. Extant studies primarily examine the governance role of internal control in accounting quality, operational efficiency, investment efficiency, asset safeguarding, agency problems, and capital costs 
(e.g., Doyle et al. 2007; Beneish et al. 2008; Dhaliwal et al. 2011; Cheng et al. 2013; Gao and Jia 2016; Cheng et al. 2018). Our study highlights the governance role of internal control in sustainable growth and provides additional evidence on its economic consequences.

Third, this study investigates the impact of multiple large shareholders on the association between internal control and sustainable growth. Our findings show that the governance role of internal control in firm's sustainable growth is more prominent in SMEs with multiple large shareholders, indicating that multiple large shareholders moderates the governance role of internal control in sustainable growth.

The remainder of this paper proceeds as follows. Section 2 develops hypotheses. Section 3 describes the data and research methodology. Section 4 presents the empirical results. The conclusions are offered in Section 5.

\section{Hypothesis Development}

\subsection{Internal Control and Sustainable Growth}

In the current wave of globalization, increasing market competition and uncertainties bring more risks to firms. Responding to the challenges, SMEs have a strong desire to manage risks through having effective internal control for sustainable growth.

Several studies have examined the practices and effectiveness of internal control in SMEs via survey, e.g., Bilgi et al. (2017) and Clika (2017) use a survey to analysis the activities and practices of SMEs' internal control in Turkish and Albania. Angeline and Teng (2016) conduct a survey to find a positive impact of internal control on sales of SMEs in Malaysia, and as well through a survey. Li et al. (2011) address the moderating effects of internal control on the relationship between knowledge exploitation and innovation in SMEs of China. However, the role of internal control in SMEs' sustainable growth is unknown.

As COSO (2013) states, internal control is a process effected by a firm to provide reasonable assurance regarding the achievement of its objectives. Managers play an important role in the design and implementation of an internal control system. The capability of managers affects the effectiveness of internal control while the effectiveness of internal control also indicates the capability of managers. Li et al. (2010) and Wang (2010) find that firms with ineffective internal control have less qualified CFOs and are more likely to change CFO. Hiring better qualified CFOs after turnover is associated with subsequent improvement in internal control effectiveness. In addition, the capability of managers has an impact on firm's sustainable growth. Extant studies (e.g., Xu and Wang 2018; Ying et al. 2019; Agostini et al. 2017) document that the capability of managers is a major determinant of the sustainable growth of a firm. Therefore, firms with effective internal control have more capable managers and higher sustainable growth.

Internal control can reduce firms' wrong decision making, and improve the efficiency of operation and investment. Feng et al. (2009) argue that ineffective internal control leads to poor-quality information, and hence managerial decision making based on low-quality information is less accurate and efficient. Cheng et al. (2013) find that ineffective internal control decreases the efficiency of investment. Caplan et al. (2018) provide additional evidence that ineffective internal control induces low quality of management decisions in mergers and acquisitions. Cheng et al. (2018) document that operation efficiency is significantly lower among firms with ineffective internal controls. More importantly, internal control is not only directly related to the efficiency of the firm's operation and investment, but also is inherently associated with internal capital allocation (D'Mello et al. 2017), and they jointly spur sustainable growth. Thus, effective internal control can enhance efficiency of operation and investment, and lead to greater sustainable growth.

Internal control can be dedicated to the decline of a firm's risk, and reduce the cost of capital. Ineffective internal control generally indicates that there are higher agency costs in the firm, such as large perks or tunneling, which bring greater risk to investors. In response to the greater risk, investors 
demand higher returns as risk compensation and let the cost of capital rise. Beneish et al. (2008) find that firms with internal control deficiencies have higher cost of equity capital. Similarly, Dhaliwal et al. (2011) show that firms with internal control weakness pay significantly higher loan rates than those without internal control weakness. Moreover, lower capital costs can give firms a resource advantage in increasing value and competitiveness, which is conducive to sustainable growth of firms. Thereby, firms with effective internal control have lower cost of capital and better sustainable growth.

In sum, internal control can perform a governance role in the sustainable growth of SMEs by enhancing management capability, improving efficiency of operation and investment and lowering cost of capital. The first hypothesis is thus proposed as follows:

Hypothesis 1. SMEs with effective internal control have higher sustainable growth.

\subsection{Internal Control, Multiple Large Shareholders, and Sustainable Growth}

Concentrated ownership in SMEs is prevailing in emerging markets such as China. SMEs with concentrated ownership usually have controlling shareholders who have the power to appoint managers and executives or take these positions themselves (Pagano and Röell 1998). They have the ability and sometimes incentives to expropriate from minority shareholders and enjoy private benefits of control. This conflict of interest between controlling and minority shareholders may affect SMEs' sustainable growth.

The existence of multiple large shareholders could either strengthen or weaken the role of internal control in SMEs' sustainable growth. One strand of studies has suggested that multiple large shareholders either compete for control (Bloch and Hege 2003) or monitor the controlling shareholder (Winton 1993; Bolton and Thadden 1998), reducing information asymmetry and agency problems, and thus enhancing the role of internal control in SMEs' sustainable growth. Another strand of literature indicates that multiple large shareholders form controlling coalitions to share private benefits (Zwiebel 1995; Gomes and Novaes 2006), intensifying information asymmetry and agency problems that lower the role of internal control.

There are a number of empirical studies on the governance role of multiple large shareholders in firm value (Volpin 2002; Attig et al. 2009), valuation of cash holdings (Attig et al. 2013), reducing the cost of equity financing (Attig et al. 2008), and increasing earnings informativeness and investment efficiency (Boubaker and Sami 2011; Jiang et al. 2018). Thus, we predict that multiple large shareholders could strengthen the role of internal control in SMEs' sustainable growth. This leads to the second hypothesis:

Hypothesis 2. The role of effective internal control on sustainable growth is more prominent in SMEs with multiple large shareholders.

\section{Methodology}

\subsection{Sample Selection}

The sample selection procedure is presented in panel A of Table 1. Our sample consists of SMEs listed in the China stock market from 2011 to 2015. Compared with large firms listed on the main board of China's stock market, SMEs listed in China's stock market are younger in age and smaller in size, have higher leverage ratio, and demonstrate more volatility in performance. After excluding 25 observations from the financial industry and 55 observations with missing data, our final sample contained 3514 firm-year observations. The data used in our study is from China Stock Market and Accounting Research (CSMAR) database. 
Table 1. Sample selection and distribution.

\begin{tabular}{|c|c|c|c|}
\hline \multicolumn{4}{|c|}{ Panel A: Sample Selection } \\
\hline \multicolumn{3}{|c|}{ Total firm-year observations available from 2011-2015 } & 3594 \\
\hline \multicolumn{3}{|c|}{ Deduct: Observations in the financial industry } & $(25)$ \\
\hline \multicolumn{3}{|c|}{ Observations with missing data } & $(55)$ \\
\hline \multicolumn{3}{|c|}{ Final sample } & 3514 \\
\hline \multicolumn{4}{|c|}{ Panel B: Sample distribution by year and ineffective internal control } \\
\hline Year & Total number of firms & $\begin{array}{c}\text { Number of firms with ineffective } \\
\text { internal control }\end{array}$ & Percentage \\
\hline 2011 & 635 & 22 & 3.46 \\
\hline 2012 & 695 & 37 & 5.32 \\
\hline 2013 & 696 & 90 & 12.93 \\
\hline 2014 & 724 & 96 & 13.26 \\
\hline 2015 & 764 & 112 & 14.66 \\
\hline Total & 3514 & 357 & 10.16 \\
\hline
\end{tabular}

Note: Percentage is the proportion of the sample with ineffective internal control relative to the total size of the sample in that year.

Panel B of Table 1 presents the distribution of our final sample by year and ineffective internal control. The proportion with ineffective internal control accounted for $10.16 \%$ of the total sample. The lowest proportion was $3.46 \%$ in 2011, and the highest proportion was $14.66 \%$ in 2015 . The sample size increased steadily due to the expansion of China's capital markets during the sample period.

\subsection{Measures of Key Variables}

\subsubsection{Sustainable Growth Rate}

A sustainable growth rate (SGR) is achieved by companies using their own funds without external financing from banks or financial markets (Higgins 1977). The sustainable growth rate is computed based on the model of Higgins (Higgins 1977):

$$
S G R=\frac{p(1-d)(1+L)}{t-p(1-d)(1+L)}
$$

where $p$ is the net profit margin on sales, $d$ is the dividend payout ratio, $L$ is the debt to equity ratio, and $t$ represents the asset turnover ratio measured by total assets to sales.

\subsubsection{Internal Control}

Following prior studies (e.g., Doyle et al. 2007; Feng et al. 2009; Cheng et al. 2018), internal control (IC) is measured as an indicator variable that equals one if the firm discloses effective internal controls with no weaknesses in that year, and zero otherwise.

\subsection{Regression Model}

To test the role of internal control in promoting sustainable growth, we estimate the following regression models:

$$
\begin{aligned}
S G R_{i, t} & =\alpha+\beta_{1} I C_{i, t}+\beta_{2} \text { Boardsize }_{i, t}+\beta_{3} \text { IndDirector }_{i, t}+\beta_{4} \text { Age }_{i, t}+\beta_{5} \text { lev }_{i, t} \\
& +\beta_{6} \text { Roa }_{i, t}+\beta_{7} \text { Size }_{i, t}+\text { Industry effects }+ \text { Year effects }+\varepsilon_{i, t} \\
S G R_{i, t}=\alpha & +\beta_{1} I_{i, t}+\beta_{2} \text { MLS }_{i, t}+\beta_{3} I C_{i, t} \times M L S_{i, t}+\beta_{4} \text { Boardsize }_{i, t}+\beta_{5} \text { IndDirector }_{i, t} \\
+\beta_{6} \text { Age }_{i, t} & +\beta_{7} \text { lev }_{i, t}+\beta_{8} \text { Roa }_{i, t}+\beta_{9} \text { Size }_{i, t}+\text { Industry effects }+ \text { Year effects }+\varepsilon_{i, t}
\end{aligned}
$$


where $S G R_{i, t}$ refers to the measure of the sustainable growth rate for firm $i$ in year $t, I C_{i, t}$ is an indicator variable that equals one if firm $i$ has effective internal controls with no weaknesses in year $t$, and zero otherwise. Hypothesis 1 predicts that the coefficient on $I C_{i, t}$ in Equation (2) is positive.

In Equation (3), following Attig et al. (2009) and Jiang et al. (2018), $M L S_{i, t}$ is a dummy variable that equals one if firm $i$ has at least two large shareholders defined as one holding $10 \%$ or more of the shareholding in year $t$, and zero otherwise. The interaction between $I C_{i, t}$ and $M L S_{i, t}$ is used to test Hypothesis 2, predicting the coefficient of interaction is positive.

To isolate the role of internal control in sustainable growth, an array of control variables is included in the regression analyses. We control for firm age (Age), leverage (Lev), return on assets (Roa) and firm size (Size) in our regression analyses. Doyle et al. (2007) demonstrate that firm-level characteristics such as firm size, firm age, financial leverage, and return on assets affect a firm's input of internal control, which finally influences the quality of internal control. As Brown et al. (2011) emphasize that corporate governance can alleviate the firm risk and promote financial performance by dealing with adverse selection and moral hazard effectively, we also include the size of board (Boardsize) and the percentage of independent directors in the board (IndDirector) to capture the effects of corporate governance. In addition, we control for industry and year effects in the regression analyses. The definition of the variables in Equation (2) is detailed in Table 2.

Table 2. Definitions of the variables.

\begin{tabular}{ll}
\hline Variables & Definitions \\
\hline SGR & $\begin{array}{l}\text { Sustainable growth rate is achieved by companies using their own funds without } \\
\text { external financing from banks or financial markets, which is estimated based on } \\
\text { Higgins' model (Higgins 1977). }\end{array}$ \\
\hline IC & $\begin{array}{l}\text { Internal control is measured as an indicator variable which equals one if the firm has } \\
\text { effective internal controls in that year, and zero otherwise. }\end{array}$ \\
\hline MLS & $\begin{array}{l}\text { A dummy variable that equals one if firm i has at least two large shareholders } \\
\text { defined as one holding } 10 \% \text { or more of the shareholding in year t, and zero otherwise. }\end{array}$ \\
\hline Boardsize & $\begin{array}{l}\text { The size of board of directors is measured as the natural logarithm of director number } \\
\text { on the board. }\end{array}$ \\
\hline IndDirector & The ratio of independent directors to total number of directors on board. \\
\hline Age & The lifetime of the firm measured as its natural log. \\
\hline Lev & Financial leverage is computed by the ratio of debt to total assets. \\
\hline Roa & Return on assets. \\
\hline Size & The natural logarithm of total assets. \\
\hline
\end{tabular}

To mitigate the influence of outliers, all continuous variables in the regression model are winsorized at the 1 percent and 99 percent levels.

\section{Empirical Results}

\subsection{Descriptive Statistics}

Table 3 shows the descriptive statistics separately for samples with ineffective internal control $(\mathrm{IC}=0)$ and samples with effective internal control samples $(\mathrm{IC}=1)$. The mean value of SGR is 0.022 in samples with ineffective internal control, which is significantly lower than the mean value of 0.051 in samples with effective internal control. This initially indicates that internal control is positively correlated with the sustainable growth rate. Among the control variables, there are significant differences between the samples with and without ineffective internal control in the terms of leverage ratio (Lev), accounting performance (Roa), firm size (Size). 
Table 3. Descriptive statistics.

\begin{tabular}{ccccccc}
\hline \multirow{2}{*}{ Variable } & \multicolumn{2}{c}{$\begin{array}{c}\text { IC }=\mathbf{0} \\
(\boldsymbol{n}=\mathbf{3 5 7 )}\end{array}$} & \multicolumn{2}{c}{$\begin{array}{c}\text { IC } \mathbf{1} \\
(\boldsymbol{n}=\mathbf{3 1 5 7})\end{array}$} & \multicolumn{2}{c}{ Difference } \\
\cline { 2 - 7 } & Mean & Median & Mean & Median & $\mathbf{t}$ & $\mathbf{z}$ \\
\hline SGR & 0.022 & 0.040 & 0.051 & 0.048 & $-4.30^{* * *}$ & $-3.20^{* * *}$ \\
MLS & 0.367 & 0 & 0.388 & 0 & -0.78 & -0.78 \\
Boardsize & 2.122 & 2.197 & 2.123 & 2.197 & -0.12 & -0.50 \\
IndDirector & 0.374 & 0.333 & 0.372 & 0.333 & 0.44 & 0.29 \\
Age & 2.402 & 2.485 & 2.368 & 2.398 & 1.54 & 0.94 \\
Lev & 0.420 & 0.418 & 0.355 & 0.331 & $5.78^{* * *}$ & $5.71^{* * *}$ \\
Roa & 0.029 & 0.033 & 0.047 & 0.045 & $-5.26^{* * *}$ & $-5.15^{* * *}$ \\
Size & 21.791 & 21.764 & 21.547 & 21.467 & $4.76^{* * *}$ & $5.14^{* * *}$ \\
\hline
\end{tabular}

Notes: SGR is the measure of sustainable growth rate estimated using Higgins' model (Higgins 1977). IC is an indicator variable that equals one if the firm has effective internal controls in that year, and zero otherwise. The difference between the samples with and without ineffective internal control are tested using the $t$-test and Wilcoxon rank-sum test. ${ }^{* * *}$ indicates two-tailed significant difference at the $1 \%$ level.

\subsection{Regression Results}

Table 4 presents the regression results of hypothesis testing. In the regression results of column (1), the coefficient on IC is positive and significant at the $5 \%$ level. The result indicates that sustainable growth rate is higher in firms with effective internal control, consistent with Hypothesis 1.

Table 4. Internal control and sustainable growth.

\begin{tabular}{|c|c|c|c|c|}
\hline \multirow{2}{*}{ Variable } & \multicolumn{4}{|c|}{ Dependent Variable $=$ SGR } \\
\hline & (1) Full Sample & (2) Full Sample & (3) $\mathrm{MLS}=0$ & (4) MLS = 1 \\
\hline IC & $\begin{array}{c}0.010^{* *} \\
(2.03)\end{array}$ & $\begin{array}{l}0.002 \\
(0.37)\end{array}$ & $\begin{array}{l}0.002 \\
(0.52)\end{array}$ & $\begin{array}{c}0.023^{* *} \\
(2.50)\end{array}$ \\
\hline MLS & & $\begin{array}{c}-0.020 * * \\
(-2.29)\end{array}$ & & \\
\hline $\mathrm{IC} \times \mathrm{MLS}$ & & $\begin{array}{c}0.022 * * \\
(2.41)\end{array}$ & & \\
\hline Boardsize & $\begin{array}{l}-0.005 \\
(-0.82)\end{array}$ & $\begin{array}{l}-0.006 \\
(-0.95)\end{array}$ & $\begin{array}{l}-0.002 \\
(-0.22)\end{array}$ & $\begin{array}{l}-0.008 \\
(-0.85)\end{array}$ \\
\hline IndDirector & $\begin{array}{l}0.010 \\
(0.37)\end{array}$ & $\begin{array}{l}0.008 \\
(0.29)\end{array}$ & $\begin{array}{l}-0.004 \\
(-0.11)\end{array}$ & $\begin{array}{l}0.057 \\
(1.40)\end{array}$ \\
\hline Age & $\begin{array}{l}-0.003 \\
(-1.28)\end{array}$ & $\begin{array}{l}-0.003 \\
(-1.15)\end{array}$ & $\begin{array}{l}-0.003 \\
(-1.14)\end{array}$ & $\begin{array}{l}-0.001 \\
(-0.18)\end{array}$ \\
\hline Lev & $\begin{array}{c}0.075^{* * *} \\
(4.03)\end{array}$ & $\begin{array}{c}0.076^{* * *} \\
(4.10)\end{array}$ & $\begin{array}{c}0.072 * * * \\
(2.78)\end{array}$ & $\begin{array}{c}0.083 * * * \\
(2.86)\end{array}$ \\
\hline Roa & $\begin{array}{c}1.472^{* * *} \\
(28.95)\end{array}$ & $\begin{array}{c}1.471^{* * *} \\
(29.15)\end{array}$ & $\begin{array}{c}1.496^{* * *} \\
(19.16)\end{array}$ & $\begin{array}{c}1.437^{* * *} \\
(13.60)\end{array}$ \\
\hline Size & $\begin{array}{c}0.006^{* *} \\
(2.03)\end{array}$ & $\begin{array}{c}0.006^{* *} \\
(2.03)\end{array}$ & $\begin{array}{l}0.008 \\
(1.40)\end{array}$ & $\begin{array}{l}0.004 \\
(1.03)\end{array}$ \\
\hline Constant & $\begin{array}{c}-0.195^{* * *} \\
(-3.20)\end{array}$ & $\begin{array}{c}-0.186^{* * *} \\
(-3.08)\end{array}$ & $\begin{array}{c}-0.223^{* *} \\
(-2.02)\end{array}$ & $\begin{array}{c}-0.142^{* * *} \\
(-2.08)\end{array}$ \\
\hline Industry effects & Yes & Yes & Yes & Yes \\
\hline Year effects & Yes & Yes & Yes & Yes \\
\hline N & 3514 & 3514 & 2158 & 1356 \\
\hline Adj. $R^{2}$ & 0.697 & 0.698 & 0.706 & 0.688 \\
\hline $\mathrm{F}$ & $52.338^{* * *}$ & $49.257^{* * *}$ & $38.853^{* * *}$ & $100.74^{* * *}$ \\
\hline
\end{tabular}

Notes: SGR is the measure of the sustainable growth rate estimated using Higgins' model (Higgins 1977). IC is an indicator variable that equals one if the firm has effective internal controls in that year, and zero otherwise. MLS equals one if the firm has at least two large shareholders defined as one holding $10 \%$ or more of the shareholding, and zero otherwise. All t-statistics in parentheses are computed using the standard errors adjusted for firm-level clustering. ${ }^{* * *}$ and ${ }^{* *}$ indicate significant difference at the $1 \%$ and $5 \%$ level, respectively. 
In the regression results of column (2), the coefficient of the interaction of IC $\times$ MLS is positive and significant at the $5 \%$ level. The result indicates that the balance of power among multiple large shareholders strengthens the role of internal control in sustainable growth, supporting Hypothesis 2. To further test the second hypothesis, the subsample regression is estimated. The full sample is divided into two subsamples based on whether a firm has at least two large shareholders. In the results of column (3) and (4), for the subsample without multiple large shareholders (MLS =0), the coefficient on IC is positive but not statistically significant. In the subsample with multiple large shareholders (MLS =1), the coefficient on IC is positive and statistically significant at the $5 \%$ level. The subsample regression results mean that the positive impact of internal control on sustainable growth is more prominent in firms with multiple large shareholders, supporting Hypothesis 2.

The results for the control variables suggest that sustainable growth is higher for firms with greater leverage ratio, firms with more profit, and larger firms.

\subsection{Robustness Tests}

We assess the credibility of our findings by conducting the following analyses. Our results are robust to these sensitivity tests.

\subsubsection{Endogeneity Issue}

Our empirical tests could suffer from endogeneity problems. Endogeneity can arise because of unobservable heterogeneity when unobservable firm-specific factors influence both internal control and sustainable growth. To control for the endogeneity, we employ Heckman's two-stage procedure (Heckman 1979) following Cheng et al. (2018). In the first stage, we estimate the following probit regression of the likelihood of having an effective internal control including its determinants:

$$
\begin{gathered}
\text { IC }_{i, t}=\alpha+\beta_{1} \text { FSale }_{i, t}+\beta_{2} \text { Age }_{i, t}+\beta_{3} \text { Segments }_{i, t}+\beta_{4} M A_{i, t}+\beta_{5} \text { Loss }_{i, t}+\beta_{6} \text { Roa }_{i, t} \\
+\beta_{7} \text { Size }_{i, t}+\text { Industry effects }+ \text { Year effects }+\varepsilon_{i, t}
\end{gathered}
$$

where IC is an indicator for observations that have effective internal controls in year $t$. The determinants include foreign sales (FSale), firm age (Age), number of business segments (Segments), merges and acquisitions or restructuring $(M A)$, an indicator for loss (Loss), return on assets (Roa), and firm size (Size). In the second stage, we put the inverse Mills ratio (IMR) calculated from the first-stage regression using Equation (4) into Equations (2) and (3) to mitigate the endogeneity problems. As shown in Table 5, after including the inverse Mills ratio, the results are similar to those in Table 4 . The coefficient of IC is statistically stronger for SGR in the regression results of column (1), supporting Hypothesis 1. In the regression results of column (2), the coefficient of interaction of IC $\times$ MLS is statistically stronger for SGR, and the subsample regression results report that the coefficient of IC is statistically stronger for SGR in the firms with multiple large shareholders (MLS =1), supporting Hypothesis 2. 
Table 5. Heckman two-stage regression results.

\begin{tabular}{ccc}
\hline & Panel A: First-Stage Regression Results \\
\hline \multirow{2}{*}{ Variable } & \multicolumn{2}{c}{ Dependent Variable = IC } \\
\cline { 2 - 3 } & Coefficient & Z-statistic \\
\hline FSale & 0.052 & 0.07 \\
Age & 0.109 & 1.39 \\
Segments & -0.117 & -1.29 \\
MA & $0.127^{*}$ & 1.76 \\
Loss & 0.063 & 0.57 \\
Roa & $2.842^{* * *}$ & 4.00 \\
Size & $-0.153^{* * *}$ & -4.07 \\
Constant & $4.715^{* * *}$ & 5.43 \\
Industry effects & Yes & \\
Year effects & Yes & \\
$N$ & 3531 & \\
Pseudo R & 0.080 & \\
LR Chi2 & $185.17^{* * *}$ & \\
\hline
\end{tabular}

\begin{tabular}{|c|c|c|c|c|}
\hline \multicolumn{5}{|c|}{ Panel B: Second-Stage Regression Results } \\
\hline \multirow{2}{*}{ Variable } & \multicolumn{4}{|c|}{ Dependent Variable $=$ SGR } \\
\hline & (1) Full Sample & (2) Full Sample & (3) $M L S=0$ & (4) $\mathrm{MLS}=1$ \\
\hline IC & $\begin{array}{c}0.010^{* *} \\
(2.12)\end{array}$ & $\begin{array}{l}0.002 \\
(0.47)\end{array}$ & $\begin{array}{l}0.003 \\
(0.69)\end{array}$ & $\begin{array}{c}0.023 * * \\
(2.55)\end{array}$ \\
\hline MLS & & $\begin{array}{c}-0.020 * * \\
(-2.27)\end{array}$ & & \\
\hline IC $\times$ MLS & & $\begin{array}{c}0.0211^{* *} \\
(2.41)\end{array}$ & & \\
\hline Boardsize & $\begin{array}{l}-0.006 \\
(-0.94)\end{array}$ & $\begin{array}{l}-0.006 \\
(-1.07)\end{array}$ & $\begin{array}{l}-0.003 \\
(-0.31)\end{array}$ & $\begin{array}{l}-0.008 \\
(-0.98)\end{array}$ \\
\hline IndDirector & $\begin{array}{l}0.011 \\
(0.40)\end{array}$ & $\begin{array}{l}0.009 \\
(0.33)\end{array}$ & $\begin{array}{l}-0.002 \\
(-0.08)\end{array}$ & $\begin{array}{l}0.056 \\
(1.41)\end{array}$ \\
\hline Age & $\begin{array}{c}0.043^{* * *} \\
(4.32)\end{array}$ & $\begin{array}{c}0.043^{* * *} \\
(4.35)\end{array}$ & $\begin{array}{c}0.046^{* * *} \\
(3.08)\end{array}$ & $\begin{array}{c}0.042 * * * \\
(3.38)\end{array}$ \\
\hline Lev & $\begin{array}{c}0.078^{* * *} \\
(4.36)\end{array}$ & $\begin{array}{c}0.079^{* * *} \\
(4.42)\end{array}$ & $\begin{array}{c}0.073^{* * *} \\
(2.94)\end{array}$ & $\begin{array}{c}0.088^{* * *} \\
(3.09)\end{array}$ \\
\hline Roa & $\begin{array}{c}1.178^{* * *} \\
(12.56)\end{array}$ & $\begin{array}{c}1.179 * * * \\
(12.65)\end{array}$ & $\begin{array}{c}1.179 * * * \\
(8.09)\end{array}$ & $\begin{array}{c}1.170^{* * *} \\
(8.23)\end{array}$ \\
\hline Size & $\begin{array}{c}0.028^{* * *} \\
(4.14)\end{array}$ & $\begin{array}{c}0.028^{* * *} \\
(4.14)\end{array}$ & $\begin{array}{c}0.031^{* * *} \\
(2.74)\end{array}$ & $\begin{array}{c}0.023^{* * *} \\
(3.42)\end{array}$ \\
\hline IMR & $\begin{array}{c}0.177^{* * *} \\
(4.89)\end{array}$ & $\begin{array}{c}0.177^{* * *} \\
(4.90)\end{array}$ & $\begin{array}{c}0.189^{* * *} \\
(3.45)\end{array}$ & $\begin{array}{c}0.163^{* * *} \\
(3.88)\end{array}$ \\
\hline Constant & $\begin{array}{c}-1.111^{* * *} \\
(-4.87)\end{array}$ & $\begin{array}{c}-1.099 * * * \\
(-4.85)\end{array}$ & $\begin{array}{c}-1.205^{* * *} \\
(-3.26)\end{array}$ & $\begin{array}{c}-0.983 * * * \\
(-3.97)\end{array}$ \\
\hline Industry effects & Yes & Yes & Yes & Yes \\
\hline Year effects & Yes & Yes & Yes & Yes \\
\hline$N$ & 3514 & 3514 & 2158 & 1356 \\
\hline Adj. $R^{2}$ & 0.704 & 0.705 & 0.714 & 0.694 \\
\hline $\mathrm{F}$ & $55.534^{* * *}$ & $52.321^{* * *}$ & $37.217^{* * *}$ & $100.07^{* * *}$ \\
\hline
\end{tabular}

Notes: SGR is the measure of the sustainable growth rate estimated using Higgins' model (Higgins 1977). IC is an indicator variable that equals one if the firm has effective internal controls in that year, and zero otherwise. IMR is calculated from first-stage regression using Equation (4). MLS equals one if the firm has at least two large shareholders defined as one holding $10 \%$ or more of the shareholding, and zero otherwise. All t-statistics in parentheses in Panel B are computed using the standard errors adjusted for firm-level clustering. ***, **, and * indicate significant difference at the $1 \%, 5 \%$, and $10 \%$ level, respectively. 


\subsubsection{Inflation-Adjusted SGR}

The firm's sustainable growth is affected by the inflation in the current year (Higgins 1977). The sustainable growth rate under inflation estimated using Equation (1) is the nominal rate, rather than the real rate. To mitigate this concern, we use inflation-adjusted SGR as the real sustainable growth rate to retest our results. The inflation-adjusted SGR is measured using the following equation.

$$
\text { Inflation -adjutedSGR }=\frac{\text { NominalSGR }+1}{1+R}-1
$$

where the nominal SGR is estimated using Equation (1) and $R$ is the inflation rate in that year. As reported in Table 6, the positive association between IC and inflation-adjusted SGR in the regression results of column (1) supports Hypothesis 1 . The coefficient of interaction of IC $\times$ MLS is statistically stronger for SGR in the regression results of column (2), and the subsample regression results report that the coefficient of IC is statistically stronger for SGR in the firms with multiple large shareholders (MLS =1), supporting Hypothesis 2.

Table 6. Internal control and inflation-adjusted SGR.

\begin{tabular}{|c|c|c|c|c|}
\hline \multirow{2}{*}{ Variable } & \multicolumn{4}{|c|}{ Dependent Variable = Inflation-Adjusted SGR } \\
\hline & (1) Full Sample & (2) Full Sample & (3) $\mathrm{MLS}=0$ & (4) $\mathrm{MLS}=1$ \\
\hline IC & $\begin{array}{c}0.010^{* *} \\
(2.05)\end{array}$ & $\begin{array}{l}0.001 \\
(0.35)\end{array}$ & $\begin{array}{l}0.002 \\
(0.50)\end{array}$ & $\begin{array}{c}0.023 * * \\
(2.54)\end{array}$ \\
\hline MLS & & $\begin{array}{c}-0.020 * * \\
(-2.33)\end{array}$ & & \\
\hline IC $\times$ MLS & & $\begin{array}{c}0.022 * * \\
(2.46)\end{array}$ & & \\
\hline Boardsize & $\begin{array}{l}-0.005 \\
(-0.81)\end{array}$ & $\begin{array}{l}-0.006 \\
(-0.94)\end{array}$ & $\begin{array}{l}-0.002 \\
(-0.19)\end{array}$ & $\begin{array}{l}-0.008 \\
(-0.88)\end{array}$ \\
\hline IndDirector & $\begin{array}{l}0.009 \\
(0.33)\end{array}$ & $\begin{array}{l}0.006 \\
(0.24)\end{array}$ & $\begin{array}{l}-0.005 \\
(-0.17)\end{array}$ & $\begin{array}{l}0.055 \\
(1.40)\end{array}$ \\
\hline Age & $\begin{array}{l}-0.003 \\
(-1.25)\end{array}$ & $\begin{array}{l}-0.003 \\
(-1.12)\end{array}$ & $\begin{array}{l}-0.003 \\
(-1.11)\end{array}$ & $\begin{array}{l}-0.001 \\
(-0.17)\end{array}$ \\
\hline Lev & $\begin{array}{c}0.073^{* * *} \\
(3.97)\end{array}$ & $\begin{array}{c}0.073^{* * *} \\
(4.04)\end{array}$ & $\begin{array}{c}0.069^{* * *} \\
(2.73)\end{array}$ & $\begin{array}{c}0.080^{* * *} \\
(2.83)\end{array}$ \\
\hline Roa & $\begin{array}{c}1.429 * * * \\
(29.02)\end{array}$ & $\begin{array}{c}1.429 * * * \\
(29.24)\end{array}$ & $\begin{array}{c}1.452 * * * \\
(19.19)\end{array}$ & $\begin{array}{c}1.398^{* * *} \\
(13.58)\end{array}$ \\
\hline Size & $\begin{array}{c}0.006^{* *} \\
(2.05)\end{array}$ & $\begin{array}{c}0.006^{* *} \\
(2.05)\end{array}$ & $\begin{array}{c}0.008 \\
(1.40)\end{array}$ & $\begin{array}{l}0.004 \\
(1.08)\end{array}$ \\
\hline Constant & $\begin{array}{c}-0.245^{* * *} \\
(-4.09)\end{array}$ & $\begin{array}{c}-0.236^{* * *} \\
(-3.97)\end{array}$ & $\begin{array}{c}-0.272^{* *} \\
(-2.51)\end{array}$ & $\begin{array}{c}-0.194^{* * *} \\
(-2.93)\end{array}$ \\
\hline Industry effects & Yes & Yes & Yes & Yes \\
\hline Year effects & Yes & Yes & Yes & Yes \\
\hline N & 3514 & 3514 & 2158 & 1356 \\
\hline Adj. $R^{2}$ & 0.696 & 0.698 & 0.706 & 0.687 \\
\hline $\mathrm{F}$ & $54.481^{* * *}$ & $51.845^{* * *}$ & $37.400^{* * *}$ & $100.34^{* * *}$ \\
\hline
\end{tabular}

Notes: Inflation-adjusted SGR is estimated using Equation (5). IC is an indicator variable that equals one if the firm has effective internal controls in that year, and zero otherwise. MLS equals one if the firm has at least two large shareholders defined as one holding $10 \%$ or more of the shareholding, and zero otherwise. All t-statistics in parentheses are computed using the standard errors adjusted for firm-level clustering. ${ }^{* * *}$ and ${ }^{* *}$ indicate significant difference at the $1 \%$ and $5 \%$ level, respectively.

\subsubsection{An Alternative Measure of Multiple Large Shareholders}

In the above test, we use $10 \%$ or more shareholding to define large shareholders, and here we redefine large shareholder using $5 \%$ shareholdings as the threshold. As presented in Table 7, the coefficient of interaction of IC $\times$ MLS is statistically stronger at 1\% level for SGR in the regression results of column (1), and the subsample regression results report that the coefficient of IC is statistically 
stronger at $1 \%$ level for SGR in the firms with multiple large shareholders (MLS $=1$ ), supporting Hypothesis 2.

Table 7. Internal control and sustainable growth.

\begin{tabular}{|c|c|c|c|}
\hline \multirow{2}{*}{ Variable } & \multicolumn{3}{|c|}{ Dependent Variable $=$ SGR } \\
\hline & (1) Full Sample & (2) $\mathrm{MLS}=0$ & (3) MLS = 1 \\
\hline IC & $\begin{array}{l}-0.003 \\
(-0.64)\end{array}$ & $\begin{array}{l}-0.002 \\
(-0.42)\end{array}$ & $\begin{array}{c}0.019^{* * *} \\
(2.78)\end{array}$ \\
\hline MLS & $\begin{array}{c}-0.020^{* * * *} \\
(-2.97)\end{array}$ & & \\
\hline $\mathrm{IC} \times \mathrm{MLS}$ & $\begin{array}{c}0.022 * * * \\
(3.16)\end{array}$ & & \\
\hline Boardsize & $\begin{array}{l}-0.006 \\
(-0.99)\end{array}$ & $\begin{array}{l}-0.008 \\
(-0.70)\end{array}$ & $\begin{array}{l}-0.004 \\
(-0.46)\end{array}$ \\
\hline IndDirector & $\begin{array}{l}0.009 \\
(0.35)\end{array}$ & $\begin{array}{l}-0.006 \\
(-0.18)\end{array}$ & $\begin{array}{l}0.029 \\
(0.87)\end{array}$ \\
\hline Age & $\begin{array}{l}-0.003 \\
(-1.15)\end{array}$ & $\begin{array}{l}-0.001 \\
(-0.23)\end{array}$ & $\begin{array}{l}-0.005 \\
(-1.41)\end{array}$ \\
\hline Lev & $\begin{array}{c}0.076^{* * *} \\
(4.09)\end{array}$ & $\begin{array}{c}0.065^{*} \\
(1.79)\end{array}$ & $\begin{array}{c}0.085^{* * *} \\
(4.14)\end{array}$ \\
\hline Roa & $\begin{array}{c}1.470 * * * \\
(29.12)\end{array}$ & $\begin{array}{c}1.424^{* * *} \\
(13.88)\end{array}$ & $\begin{array}{c}1.507^{* * * *} \\
(18.43)\end{array}$ \\
\hline Size & $\begin{array}{c}0.006^{* *} \\
(1.99)\end{array}$ & $\begin{array}{l}0.009 \\
(1.10)\end{array}$ & $\begin{array}{c}0.005^{*} \\
(1.73)\end{array}$ \\
\hline Constant & $\begin{array}{c}-0.180^{* * * *} \\
(-2.98)\end{array}$ & $\begin{array}{l}-0.221 \\
(-1.37)\end{array}$ & $\begin{array}{c}-0.181^{* * *} \\
(-3.10)\end{array}$ \\
\hline Industry effects & Yes & Yes & Yes \\
\hline Year effects & Yes & Yes & Yes \\
\hline N & 3514 & 1437 & 2077 \\
\hline Adj. $R^{2}$ & 0.698 & 0.675 & 0.716 \\
\hline $\mathrm{F}$ & $51.178^{* * *}$ & $100.50^{* * *}$ & $25.939 * * *$ \\
\hline
\end{tabular}

Notes: SGR is the measure of the sustainable growth rate estimated using Higgins' model (Higgins 1977). IC is an indicator variable that equals one if the firm has effective internal controls in that year, and zero otherwise. MLS equals one if the firm has at least two large shareholders defined as one holding $5 \%$ or more of the shareholding, and zero otherwise. All t-statistics in parentheses are computed using the standard errors adjusted for firm-level clustering. ${ }^{* * *}, * *$, and ${ }^{*}$ indicate significant difference at the $1 \%, 5 \%$, and $10 \%$ level, respectively.

\section{Conclusions}

The purpose of internal control to promote sustainable growth of a firm is underlined in the report issued by COSO (2017). However, there is little empirical evidence on the governance role of internal control in sustainable growth of SMEs, especially with moderation effects of multiple large shareholders.

This study aims to examine the governance role of internal control in SMEs' sustainable growth in the developing economy of China with the moderation effect of multiple large shareholders. Using a sample of SMEs listed in the China market from 2011 to 2015, we find that internal control significantly positively contributes to SMEs' sustainable growth, supporting Hypothesis 1 . This provides the empirical evidence for the claim of COSO (2017) that one of the goals of internal control aims to keep and improve sustainable growth.

Moreover, the governance role of internal control in SMEs' sustainable growth is moderated by the balance of power among multiple large shareholders. Jiang et al. (2018) contend that multiple large shareholders have a governance role in corporate investment. We extend the line of the research and document that the governance role of internal control in sustainable growth is more pronounced for SMEs with multiple large shareholders, which particularly supports Hypothesis 2. 
The above results are robust to a battery of sensitivity tests, including control for endogeneity using the Heckman two-stage procedure, and alternative proxies for sustainable growth and multiple large shareholders.

Our findings suggest that effective internal control not only helps firms improve investment and operation efficiency, as documented in prior studies, but also exercises a governance role in SMEs' sustainable growth with moderation effects of multiple large shareholders. Our study extends the line of the research by providing evidence from the largest emerging economy of China and has implications for other emerging economies.

Author Contributions: L.W. devised and designed the research, developed the hypotheses, carried out data analysis and reviewed the paper; Y.D. (Yining Dai) and Y.D. (Yuye Ding) have helped in data collection and analysis, writing the preliminary draft of the paper, and revision.

Funding: The research is supported by the National Science Foundation of China (71302132 and 71932003), Social Science Key Project of Sichuan Province of China (SC17A010), and the research fund from Sichuan University (SKQY201650).

Acknowledgments: We would like to thank the three anonymous reviewers who carefully reviewed our paper and provided us with intuitive suggestions and constructive comments. We are grateful to the editors for their support and effort for our manuscript.

Conflicts of Interest: The authors declare no conflict of interest.

\section{References}

Acharya, Viral V., Stewart C. Myers, and Raghuram G. Rajan. 2011. The Internal Governance of Firms. Journal of Finance 66: 689-720. [CrossRef]

Agostini, Lara, Anna Nosella, and Roberto Filippini. 2017. Does Intellectual Capital Allow Improving Innovation Performance? A Quantitative Analysis in the SME Context. Journal of Intellectual Capital 18: 400-18. [CrossRef]

Angeline, Yap Kiew Heong, and Yap Saw Teng. 2016. Enterprise risk management: Evidence from SMEs. Malaysian Accounting Review 15: 151-70.

Attig, Najah, Omrane Guedhami, and Dev Mishra. 2008. Multiple Large Shareholders, Control Contests, and Implied Cost of Equity. Journal of Corporate Finance 14: 721-37. [CrossRef]

Attig, Najah, Sadok El Ghoul, and Omrane Guedhami. 2009. Do Multiple Large Shareholders Play a Corporate Governance Role? Evidence from East Asia. Journal of Financial Research 32: 395-422. [CrossRef]

Attig, Najah, Sadok El Ghoul, Omrane Guedhami, and Sorin Rizeanu. 2013. The Governance Role of Multiple Large Shareholders: Evidence from the Valuation of Cash Holdings. Journal of Management \& Governance 17: 419-51.

Bauer, Andrew, Darren Henderson, and Daniel P. Lynch. 2018. Supplier Internal Control Quality and the Duration of Customer-Supplier Relationships. The Accounting Review 93: 59-82. [CrossRef]

Beneish, Messod Daniel, Mary Brooke Billings, and Leslie D. Hodder. 2008. Internal Control Weaknesses and Information Uncertainty. Accounting Review 83: 665-703. [CrossRef]

Bennedsen, Morten, and Daniel Wolfenzon. 2000. The Balance of Power in Closely Held Corporations. Journal of Financial Economics 58: 113-39. [CrossRef]

Bilgi, Ismail, Lyudmila Mihaylova, and Emil Papazov. 2017. Internal control activities in small Turkish companies. Journal of Contemporary Management Issues 22: 69-83.

Bloch, Francis, and Ulrich Hege. 2003. Multiple Shareholders and Control Contests. Available online: https: //ssrn.com/abstract=2273211 (accessed on 29 September 2003).

Bolton, Patrick, and Ernst-Ludwig Von Thadden. 1998. Blocks, Liquidity, and Corporate Control. Journal of Finance 53: 1-25. [CrossRef]

Boubaker, Sabri, and Hind Sami. 2011. Multiple Large Shareholders and Earnings Informativeness. Review of Accounting and Finance 10: 246-66. [CrossRef]

Brown, Philip, Wendy Beekes, and Peter Verhoeven. 2011. Corporate governance, accounting and finance: A review. Accounting and Finance 51: 96-172. [CrossRef]

Bushman, Robert M., and Abbie J. Smith. 2001. Financial Accounting Information and Corporate Governance. Journal of Accounting \& Economics 32: 237-333. 
Caplan, Dennis H., Saurav K. Dutta, and Alfred Zhu Liu. 2018. Are Material Weaknesses in Internal Controls Associated with Poor M\&A Decisions? Evidence from Goodwill Impairment. Auditing: A Journal of Practice E Theory 37: 49-74.

Cheng, Mei, Dan Dhaliwal, and Yuan Zhang. 2013. Does Investment Efficiency Improve after the Disclosure of Material Weaknesses in Internal Control over Financial Reporting? Journal of Accounting E Economics 56: $1-18$.

Cheng, Qiang, Beng Wee Goh, and Jae B. Kim. 2018. Internal Control and Operational Efficiency. Contemporary Accounting Research 35: 1102-39. [CrossRef]

Clika, Nertila. 2017. An analysis of practices of internal controls in Small and Medium Enterprises in Albania. Journal of Accounting and Management 7: 87-97.

Committee of Sponsoring Organizations of the Treadway Commission. 2013. Internal Control-Integrated Framework: Executive Summary. New York: COSO.

Committee of Sponsoring Organizations of the Treadway Commission. 2017. Enterprise Risk Management-Integrated with Strategy and Performance: Executive Summary. New York: COSO.

D'Mello, Ranjan, Xinghua Gao, and Yonghong Jia. 2017. Internal Control and Internal Capital Allocation: Evidence from Internal Capital Markets of Multi-Segment Firms. Review of Accounting Studies 22: 251-87. [CrossRef]

Dhaliwal, Dan, Chris Hogan, Robert Trezevant, and Michael Wilkins. 2011. Internal Control Disclosures, Monitoring, and the Cost of Debt. Accounting Review 86: 1131-56. [CrossRef]

Doyle, Jeffrey T., Weili Ge, and Sarah McVay. 2007. Accruals Quality and Internal Control over Financial Reporting. Accounting Review 82: 1141-70. [CrossRef]

Feng, Mei, Chan Li, and Sarah McVay. 2009. Internal Control and Management Guidance. Journal of Accounting $\mathcal{E}$ Economics 48: 190-209.

Gao, Xinghua, and Yonghong Jia. 2016. Internal Control over Financial Reporting and the Safeguarding of Corporate Resources: Evidence from the Value of Cash Holdings. Contemporary Accounting Research 33: 783-814. [CrossRef]

Ge, Baoshan, Yibing Yang, Dake Jiang, Yang Gao, Xiaomin Du, and Tingting Zhou. 2018. An Empirical Study on Green Innovation Strategy and Sustainable Competitive Advantages: Path and Boundary. Sustainability 10: 3631. [CrossRef]

Gomes, Armando, and Walter Novaes. 2006. Sharing of control versus monitoring as corporate governance mechanisms. Unpublished Working Paper.

Heckman, James J. 1979. Sample selection bias as a specification error. Econometrica 47: 153-61. [CrossRef]

Higgins, Robert C. 1977. How Much Growth Can a Firm Afford? Financial Management 6: 7-16. [CrossRef]

Hong, Lucheng, and Angela Chao. 2018. Strategic corporate social responsibility, sustainable growth, and energy policy in China. Sustainability 11: 3024. [CrossRef]

Jensen, Michael C. 1993. The Modern Industrial Revolution, Exit, and the Failure of Internal Control Systems. The Journal of finance 48: 831-80. [CrossRef]

Jiang, Fuxiu, Wenjing Cai, Xue Wang, and Bing Zhu. 2018. Multiple Large Shareholders and Corporate Investment: Evidence from China. Journal of Corporate Finance 50: 66-83. [CrossRef]

Li, Chan, Lili Sun, and Michael Ettredge. 2010. Financial Executive Qualifications, Financial Executive Turnover, and Adverse SOX 404 Opinions. Journal of Accounting \& Economics 50: 93-110.

Li, Yuan, Xiyao Li, Yi Liu, and Bradley R. Barnes. 2011. Knowledge communication, exploitation and endogenous innovation: The moderating effects of internal controls in SMEs. RED Management 41: 156-72.

Lyver, Maurice J., and Ta-Jung Lu. 2018. Sustaining Innovation Performance in SMEs: Exploring the Roles of Strategic Entrepreneurship and IT Capabilities. Sustainability 10: 442. [CrossRef]

Ma Degong, Farid Ullah, Muhammad Sualeh Khattak, and Muhammad Anwar. 2018. Do International Capabilities and Resources Configure Firm's Sustainable Competitive Performance? Research within Pakistani SMEs. Sustainability 10: 4298. [CrossRef]

Pagano, Marco, and Ailsa Röell. 1998. The Choice of Stock Ownership Structure: Agency Costs, Monitoring, and the Decision to Go Public. Quarterly Journal of Economics 113: 187-225. [CrossRef]

Paletta, Angelo, and Genc Alimehmeti. 2018. SOX Disclosure and the Effect of Internal Controls on Executive Compensation. Journal of Accounting, Auditing \& Finance 33: 277-95.

Qi, Baolei, Liuchang Li, Qing Zhou, and Jinghui Sun. 2017. Does internal control over financial reporting really alleviate agency conflicts. Accounting and Finance 57: 1101-25. [CrossRef] 
Shleifer, Andrei, and Robert W. Vishny. 1986. Large Shareholders and Corporate Control. Journal of Political Economy 94: 461-88. [CrossRef]

Skaife, Hollis A., David Veenman, and Daniel Wangerin. 2013. Internal control over financial reporting and managerial rent extraction: Evidence from the profitability of insider trading. Journal of Accounting $\mathcal{E}$ Economics 55: 91-110.

Volpin, Paolo F. 2002. Governance with Poor Investor Protection: Evidence from Top Executive Turnover in Italy. Journal of Financial Economics 64: 61-90. [CrossRef]

Wang, Xue. 2010. Increased disclosure requirements and corporate governance decisions: Evidence from chief financial officers in the pre- and post-Sarbanes-Oxley periods. Journal of Accounting Research 48: 885-920. [CrossRef]

Winton, Andrew. 1993. Limitation of liability and the ownership structures of the firm. Journal of Finance 48: 487-512. [CrossRef]

Xu, Jian, and Binghan Wang. 2018. Intellectual capital, financial performance and companies' sustainable growth: Evidence form the Korean manufacturing industry. Sustainability 10: 4651. [CrossRef]

Ye, Jianmu, and Kmmcb Kulathunga. 2019. How does financial literacy promote sustainability in SMEs? A developing country perspective. Sustainability 11: 2990. [CrossRef]

Ying, Qianwei, Hassan Hazrat, and Ahmad Habib. 2019. The role of a manager's intangible capabilities in resource acquisition and sustainable competitive performance. Sustainability 11: 527. [CrossRef]

Zwiebel, Jeffrey. 1995. Block Investment and Partial Benefits of Corporate Control. Review of Economic Studies 62: 161. [CrossRef]

(C) 2019 by the authors. Licensee MDPI, Basel, Switzerland. This article is an open access article distributed under the terms and conditions of the Creative Commons Attribution (CC BY) license (http://creativecommons.org/licenses/by/4.0/). 